\title{
Tosho Rafailov
}

ORICD: 0000-0003-1128-2747

"Neofit Rilski" Primary School

Kilifarevo, Bulgaria

\section{SPECIFICITY OF TEACHING ENGLISH TO STUDENTS WITH SPECIAL EDUCATIONAL NEEDS}

\author{
https://doi.org/10.34739/sn.2020.20.05
}

\begin{abstract}
Abstrakt: The specificity of teaching and learning English for children with special educational needs is the result of the process of implementation of innovative technologies for developing communication skills. Teaching methods are: brainstorming / ice breaking game /; video presentation / multimedia presentation /; doll show; frontal talk; solving crossword puzzles; individual work for the faster. The training is carried out in an innovative learning environment at the "Neofit Rilski" Primary School in Kilifarevo. The expected results of teaching and learning can be represented by the significantly higher annual achievement of students with special needs. Teaching requires the teacher to prepare the academic content on a scientific basis. The scientific basis of the English lesson involves the use of the Multiple Intelligence Theory. The interest in innovative training is strongly emphasized by students with special needs.
\end{abstract}

Keywords: teaching, training, English, children with special needs

\section{Introduction}

The relevance of the problem under study is determined by the need to improve the quality of teaching and learning in English for students with special needs. The specifics of "Innovative Schools" imply a diversification of the learning process by introducing more technologies in classrooms / working with smart applications, tablets, virtual boards, and virtual classrooms / by changing the learning environment and the length of class.

The specific essential dimensions of teaching and learning English to students with special needs are presented as: a scientifically sound 
and proven prescription; it offers opportunities for a variety of practical solutions to solve the problem of communicative skills, according to the specific situation of learning English in an innovative school [Rangelova, 2009, p. 26-27]; technology contains elements of standardization and innovation in teaching English to students with special needs; innovative technology has a complex and hierarchical nature, revealing a complex of communication mechanisms that can solve a given problem; the effectiveness of the technology of developing communication skills in teaching English to students with special educational needs is established through empirical verification of results [Rangelova, 2009, p. 26-27]; in the technology of developing communicative skills in teaching and learning English to students with special educational needs, they are combined in dialectical unity with the technology of student activity and the technology of teacher activity; it is flexible and diverse in terms of students and personalized in the activities of the teacher; technology does not exclude the manifestation of creativity and innovation in the implementation of pedagogical interaction [Rangelova, 2009, p. 26-27].

Modern teaching technologies suggest that students with special needs need the same level of education as other students and have the same knowledge, skills, and habits in the English language course.

Innovative learning content, curricula and plans in English comply with the eligibility criteria adopted by the relevant authorities. The specifics of teaching and learning English for children with special needs are as follows: pragmatic orientation of learning and active position of students in it; the new vision of the teacher's role in English language teaching; changed / new / communication structure in the English lesson.

The education of children with special needs requires good theoretical and practical training of teachers, motivation for work, and extensive educational and socio-therapeutic practice [Zheleva, 2019, p. 75].

The degree of impact of the established model for the optimal organization and implementation of the specificity of teaching and learning in English used for students with special educational needs implies: awareness of parents and students about the new technology of teaching and learning; motivation for forming communication skills in 
English; inner conviction of the need to build communication skills in English; display of tolerance in communication in English.

\section{Purpose}

The purpose of the scientific communication is to reveal and outline the organizational pedagogical conditions and effectiveness of innovative teaching and training of students with special needs in English at the "Neofit Rilski" Primary School in Kilifarevo.

\section{Material and methods}

The objectives of the study are to reveal the role and specificity of the teaching and learning of students with special needs in English. During the research, the following methods were used: questionnaire, purposeful including observation, and pedagogical experiment. The object of the study are students with special needs in the "Neofit Rilski" Primary School in Kilifarevo. The subject of the research is the process and conditions in which teaching and learning English through innovative technologies is a condition and a factor for better learning of knowledge and skills of students with special needs.

\section{Results and discussion}

The analysis of the survey among the respondents shows that the specificity of teaching and learning English for students with special educational needs provides $100 \%$ awareness from parents and $89 \%$ from students. Purposeful included monitoring of the new technology for teaching English has proven the conditions created for the continuous acquisition of communication skills in English by students with special educational needs.

The conducted pedagogical experiment proved the specificity of the optimized interaction: English teacher - a student with special educational needs. The research has shown that the specificity of teaching and learning in English requires the use of interactive methods that overcome the reproductive teaching style. The transition from quantitative dimensions of learning to quality assimilation is facilitated. 
Supporting students' behavioral change through group communication aimed at engaging in different roles and learning through the experiences of participants in interactive learning.

The research conducted among parents of students with special educational needs showed the need for increased demand on the teacher as the main source of information; he must become a process moderator, expert, consultant, organizer, and leader in the group; to provide a relaxed emotional atmosphere during teaching and learning; functionally role his role in approaching the concept of reflective teaching.

Specificity in the teaching and learning of students with special educational needs requires intensification not only of communication between the teacher and students, but also of the interaction between the students themselves. The study further proved that students need to become active participants in the learning process and to be able to change their course through their own experiences and experiences. The percentage of respondents expecting a teacher-student communication to have a decentralized structure is high.

\section{Conclusion}

Specificity in teaching and learning English to students with special educational needs includes active learning in innovative English teaching. To achieve this, the teacher applies: a person-centered approach; intensive communication; frequent change of activities and increased emotional of the process. The emphasis is on feelings, not just rational thinking about the material. Reflection makes self-assessment, analysis, and commentary on the work done by the teacher and the student with special educational needs.

Specificity in the teaching and learning of English to students with special educational needs requires the application of the Dale's Learning Cone, where the teacher in an interactive English lesson includes: reading; listening; observation; observation and explanation; discussion; questions; small group work; practical exercises; projects; tasks and essays. 


\section{Literature}

Rangelova E. (2009), Methodology of Educational Activity, ECS-PRES, Gabrovo.

Zheleva E. (2019), The specific in the training of healthcare specialists for children and adults with special needs, [in:] T. Zacharuk (red.), Edukacja inkluzyjna. Synergia działań, Siedlce, p. 69-75. 